\title{
IDENTIDAD E IMAGINARIOS URBANOS EN LIMA NORTE.
}

\author{
Pedro Jacinto Pazos \\ Universidad Ricardo Palma \\ jacintopazos@hotmail.com
}

\section{RESUMEN}

Se explica de alguna forma la percepción de los vendedores en la calle ("ambulantes") en relación con los monumentos y patrimonio cultural del Centro Histórico de la capital. En realidad, los padres y los hijos de los migrantes provincianos que ya no ven a la Lima tradicional y criolla, como la posesionaria exclusiva de los espacios culturales limeños, sino más bien, ésta la observan, como un espacio más abierto e inclusivo, a pesar de algún reducido grupo de citadinos $u$ originarios que cree aún, manejar como propiedad, privilegiados espacios públicos.

\section{PALABRAS CLAVE}

Imaginarios urbanos / Identidad / Vendedores en la calle / Lima Norte.

\begin{abstract}
It is explained the perception of the street vendors in relation to the monuments and cultural heritage of the historic center of the Capital. In fact, parents and children of the provincial migrants who don't see Lima as the Creole, and traditional, such as the exclusive possession of the Lima cultural spaces, despite this group see, as a more open and inclusive space, despite small group of citizens or originate who still believe to manage like property, these exclusive public spaces.
\end{abstract}

\section{KEYWORDS}

Urban imaginaries / Identity / Street vendors / North Lima. 


\section{INTRODUCCIÓN}

La presente investigación trata de analizar la identidad, la cultura y los imaginarios urbanos de Lima desde la percepción de los vendedores en la calle que se ubican alrededor de los shopping centers de Lima Norte. Se observa Lima, a partir de su Centro Histórico desde sus principales símbolos, imágenes y lugares históricos (monumentos, catedrales, parques y distritos.) representativos para el mundo migrante y los nuevos limeños de pleno siglo XXI. Es desde esta confrontación que se estudia el imaginario y los espacios relacionales que se van transformando en lugares de identidad y de cultura en esta población, mirando a la vez los sentidos de conflicto racial-étnico que frente a los limeños citadinos se les puede presentar. Se explican los imaginarios urbanos que hacen posible identidades en construcción en individuos que se encuentran en constante competencia bajo ámbitos económicos y, también, culturales. Son vendedores en la calle ("ambulantes") en decidida confrontación diaria con el capital mercantilista en sí, a la vez que con las imagenes que frente a ella se les va re-creando en la Lima actual. Las preguntas centrales de la propuesta se rigen por las siguientes interrogantes: ¿Existen en los vendedores en la calle parámetros establecidos que hacen posible una confrontación o una des-relación de Lima como Capital desde sus imágenes, símbolos y lugares históricos? y, desde estas lógicas, ¿De qué manera, desde sus imaginarios urbanos se representan una identidad limeña los descritos sujetos sociales en escena? Los presupuestos los explicamos de la siguiente manera: (a) Los últimos cambios y trasformaciones, que se están observando en la ciudad de Lima durante la última década está llevando a recrear nuevos imaginarios urbanos, reproduciendo en sí nuevas identidades y manifestaciones culturales en los vendedores en la calle, que está generando una relación subjetiva - cultural de proximidad con una cierta simbología espacial capitalina limeña. (b) Los referentes identitarios sobre los cuales los vendedores en la calle se expresan son parte de una conflicto socio-cultural que muchas veces se presenta como una esfera de inclusión y homogeneidad, cuando en realidad son manifestaciones de dominación cultural y simbólica que tiene como escenario el control financiero y comercial bajo el predominio del capital ${ }^{1}$.

1 Son hipótesis que en realidad vengo trabajando a manera de seguimiento en esta parte de Lima Norte, con la intención de hacer un análisis comparativo, entre los distintos sujetos sociales en escena, en un primer momento lo realizamos con los microempresarios en conjunto y ya, esta vez a los vendedores en la calle en específico. 
Los resultados están dirigidos a explicar la identidad y la cultura limeña por parte de estos vendedores ambulantes. Sus cotejos e imaginarios frente a la ciudad Capital. Un análisis a discutir, donde se explica que en realidad, Lima tiene una nueva forma de ser mirada, por los pobladores de la zona de Lima Norte. Es bastante, elocuente, que donde se supone, se pueden cruzar todas la reminiscencias de un pasado de migrante "sojuzgado" y "racializado", las imágenes y las representaciones que sobre la Capital se presentan en los vendedores de calle tienen visos de orientar sus percepciones hacia una Lima mucho más abierta y más incluyente, donde se puede decir existe a la vez, un sentido de adhesión por el trabajo, por la familia o hasta por la modernización que el mismo carácter cultural impone y que, aún sigue latente, en la Capital. Es decir, no se dejan aún los conceptos históricos que sobre la socialización, redistribución cultural y, la reciprocidad; se presentan junto a las nociones de mercado y de capital (o capitalismo) predominante en el país.

\section{LA IDEA DE IDENTIDAD EN EL PERÚ: OTROS HORIZONTES.}

Lo que analizamos es la idea de identidad desde sus distintas variantes y según las propuestas que en el país se han establecido. Entendiendo, de prioridad para el caso latinoamericano y peruano, que lo racial y lo cultural no definen una identidad sino sus implicancias históricas que sobre dicha noción se ha establecido, sea externa o internamente, donde lo más notable son los rasgos económico-sociales, en un contexto de pluralidad cultural $^{2}$. La identidad se encuentra asociada a un contexto relacional donde palabras o categorías tantas veces excluyentes como las de "raza" y "etnia" pueden reducir las ideas que bajo la diversidad cultural se expresan en el país ${ }^{3}$. Esto lleva a explicarnos de igual modo que la identidad no se relaciona solamente a contextos de historias locales o regionales, sino está circunscrita a una serie de procesos culturales, hoy muchas veces más complejos con la globalización a cuestas. En consecuencia, la identidad y su correlato la cultura se rige por los modos en que las prácticas sociales y cotidianas, se manifiestan al interior de los individuos y las colectividades.

Ver: Quijano, 1992.

Expresa este autor, que: "El replanteamiento radical de las ideas de nación y de identidad nacional, como legitimación de la diversidad en la especie y en la experiencia histórico-cultural (fuera de los estereotipos coloniales de 'raza'y de 'etnia'); como riqueza deseable y necesaria de toda existencia social colectiva. No hay en la historia actual curso distinto para ningún abordaje del problema de la identidad en esta sociedad". (Quijano, 1992c: 10-11) 
Por lo tanto, esta identidad, se hace de igual forma cambiante de acuerdo a las maneras de recreación o reproducción que en los ámbitos sociales se presenta, sobre todo en países como los nuestros donde los sentidos de exclusión y discriminación socio-étnica, son relaciones cuasi inmutables en la sociedad peruana ${ }^{4}$. Y donde, los sentidos de subordinación y dominación que políticas neoliberales como las nuestras exteriorizan. La antropología ha dado cuenta de estos fenómenos desde sus orígenes, tal como lo revela la etnografía. Y, es precisamente, por la transmisión de saberes y de subjetividades que observamos el discurso de las imágenes, los códigos, las categorías y los lenguajes de los "otros", los "exóticos" que vistas desde nuestras perspectivas es para sensibilizar, los afectos y las alegrías que en dichas declaraciones identitarias se forman. Esto sigue siendo un gran debate, incluido, en parte por los postmodernistas actuales, cuya solución fue explicarnos que ambas percepciones del sujeto investigado y el sujeto investigador no son verdades sino ficciones acumuladas en ambos sujetos sociales $^{5}$. En sí, de parte de quienes recepcionan aquellas elaboraciones orales identitarias y de aquéllos que lo pronuncian o la conceden. Fue Carlos Franco (1985) quien publicó un artículo ${ }^{6}$ donde exponía que:

La identidad nacional peruana no es más ni un problema ni una posibilidad. La nación peruana existe como una nación culturalmente chola, aunque presente las heterogeneidades, vertientes y diversidades que podemos encontrar en cualquier otra formación nacional constituida. El nombre del Perú por tanto no refiere sólo un Estado o un territorio, ni es exclusivamente el escenario histórico en que convergen y divergen azarosamente un conjunto múltiple de procesos esencialmente paralelos. El nombre del Perú y su desarrollo adquieren ahora la unidad de un proceso histórico basado en la expansión de la identidad de una nación chola constituida. (Franco, 1985, p. 16).

Esta es una propuesta que hoy día parece ser obsoleta, no obstante, aún continuar en discusión. En sí, para ubicar el contexto en que se piensan las distintas categorías socio-étnicas que se han venido elaborando, y sobre

4 Una nueva investigación en curso realizada con maestros de educación básica en Huánuco, me lleva a sostener aún la continuidad de las ideas racistas impregnadas en la subjetividad de la población peruana. Ver Jacinto Pazos, 2013.

5 Ver: J. Clifford (1988).

6 Ver: Franco (1993b). 
todo la constitución e identidad de una nación cuya característica central es el de ya, "ser chola constituida", dejando de buscar así, otras categorías que impliquen la confusión respecto a la caracterización de la sociedad peruana, forjando así, una mirada no homogénea del proceso sino de cómo se constituye una diversidad cultural como la que se establece en el país. Es la búsqueda de nuevos horizontes donde la historia, obliga una mirada más integral a una sociedad en constitución desde su cultura, la cual va concibiendo una identidad bajo nuevas formas de peruanidad, pero donde la idea de relaciones de trabajo se hace presente para el caso del mundo migrante peruano, que puede a la vez, resquebrajar la re-construcción de un pensamiento. En el debate el problema existencial del país y su sentir futuro. Todo esto también, nos acerca de algún modo a Guillermo Nugent $(1992)^{7}$, cuando analizando el sumario cultural peruano en función a esta migración interna que se desarrolla desde Lima, explica que:

La peculiaridad y extrema importancia de este proceso es que las relaciones sociales desplegadas en la ciudad, entraron en contradicción con la atribución de la condición indígena. Se trató "como si" fuera indio a quien justamente no podía tratarse así, a consecuencia de la fluidez y movilidad de las relaciones urbanas. Aquí tenemos un caso ilustrativo y típico de cómo una expresión puede tener significado según los usos que se le dé. El indio urbano no era un mero trasplante espacial, una simple intrusión, como de hecho se lo intento representar. Con el tiempo, esa presencia fuera de lugar dio origen a una identidad que al principio nadie reconoció como tal: cholo. No hay palabra que en el Perú sea tan usada para propósitos tan distintos: lo mismo puede ser válida para expresar el rechazo y exclusión totales: ¡Cholo de porquería!, como puede ser usada para extender o subrayar una cercanía o intimidad: cholo, cholita, cholito, Y naturalmente no se trata de un defecto del significado. Generalmente su uso atiende a reglas bien precisas y hasta es probable que del inicial predominio despectivo del uso estemos pasando a un uso más propiamente natural, de un carácter preferentemente inclusivo. El paso de ser un estigma venenoso a rasgo natural de la vida social. (Nugent, 1992, p. 76).

7 Existe versión, 2013; con el, Posfacio: El agua está del otro lado. En sí, la discusión del no racismo en el Perú. Ver: Nugent Guillermo (2013). El laberinto de la choledad. Páginas para entender la desigualdad. Lima: UPC. 
Como se acota, hemos insistido, de algún modo en ciertas aristas relacionados a la 'identidad', 'lo andino' y 'lo mestizo', aunque priorizando las perspectivas descriptivas-teóricas que dichas ideas presentan. Aquí, la imagen de "lo cholo" tiene, una connotación mucho más representativa desde las lógicas del grupo social que investigamos. Y que además, no solo se trata de su connotación étnica - racial, como tal, sino de lo que ello representa en el futuro como grupo emergente competitivo e inclusivo en los ámbitos del mercado y sobre todo de la cultura, de la cual siempre se trató de excluirlos. Esto pensando actualmente a los hijos que se miran, como descendientes de una Capital que las hace suya, sin las consecuencias que tuvieron los padres cuya primera experiencia se asentaba en la diferencia étnica-cultural. Sin contar ya la fuerte desigualdad social existente entre los mismos. Más aún, desde una modernización que los lleva a pensar Lima de distinta forma, ya bajo su posesión y merced. Son desde estas ideas que el concepto de indio urbano se impone como mediador o tránsito en la población limeña y, cuya re-significación desde el grupo "cholo", lo observamos en pleno siglo XXI, y ya no como el "cholu" histórico que implicó el estigma racial desde la colonia hasta el siglo pasado ${ }^{8}$. Es decir, se van por las cuatro generaciones que nacen en Lima, que orientan y guían a los padres en ámbitos y espacios que de alguna manera les eran ajenos. En realidad, en esta parte de Lima Norte, los hijos los vemos en una tercera generación, con una apabullante migración en constante desarrollo.

Por aquellos años las orientaciones de los trabajos en ciencias sociales se dirigían al estudio de las 'mentalidades populares', que de alguna forma también implicaba la idea de identidad. En dichos trabajos dirigidos por Gonzalo Portocarrero (1993), encontramos la idea de mentalidad popular en su forma representativa de lo que desde la antropología se operacionaliza como cultura. Aquí se ve, el grupo cholo como el de mayor movilización e influencia en la sociedad peruana. La identificación de los hijos de los migrantes con el barrio pero la falta de sentimiento de identificación con Lima. Decía el autor: "Pero en todo caso, aun reconociendo estos hechos, el énfasis puesto en el análisis de la cultura de los migrantes andinos puede justificarse. De hecho el grupo cholo es el grupo más movilizado de la sociedad peruana. Muestra una gran vitalidad y su influencia se deja sentir sobre mestizos, criollos y blancos. Vive la epopeya del cambio, el reto de asimilar lo moderno sin desarraigarse, de recrear sus tradiciones, de no perder su alma”. (Portocarrero, 1993: 29). Si bien el autor, pretende desligarse de la

8 Ver Quijano, 1988. 
"cultura", nos devuelve la noción desde la subjetividad y la producción de conocimientos que desde hace muchos años la vieja antropología redime?

Son los años en que se presenta una visión reducida del fenómeno cultural urbano, no obstante una salida hacia una búsqueda de la emergencia del nuevo limeño en proceso de consolidación y construcción. Efectivamente, el tema como referente conceptual y empírico tiene su análisis bajo características propias de la oposición existente en la sociedad peruana desde lo indio-misti, o lo indio-blanco y ya últimamente desde lo indio-criollo o cholo-criollo. Vista de esta manera la idea de identidad implicaría solamente características socio-étnicas reduccionistas, cuando en realidad detrás de ella se encuentran nociones complementarias que el mismo proceso social de los individuos y las colectividades proveen. Así es el caso de la lengua quechua, como componente matriz que también rige rasgos identitarios que tutelan la vida cotidiana de las personas. Pero también, se observa, que las mismas en su proceso evolutivo ceden ante los embates de la modernización y pierden sus espacios como idioma y como origen histórico de quienes la practican. Desde luego, para el caso de los "microempresarios" investigados son en mínima proporción los que se ubican bajo esta categoría. Sin embargo hay que entender que hay espacios sociales que hacen del individuo ostentar rasgos y características propias, que marcan orígenes muy distintos a las de la lengua, donde los rasgos físicos o la entonación de la voz de las personas están presentes. Indudablemente, esta ha sido una preocupación de Rodrigo Montoya (2010) durante gran parte de sus investigaciones, tratando de observar cómo el porvenir de la cultura quechua se encuentra en franca decadencia en la Capital a partir de las nuevas generaciones, no obstante, surgir un optimismo desde los movimientos políticos indígenas que hacen posible ubicar una nueva mirada al mundo quechua ${ }^{10}$. De alguna manera, las

9 Desde luego, que concordamos con Portocarrero, en su introducción a Las Clases medias (1998), cuando explica, que existe una clase media emergente cuyo consumo cultural e identidad siguen pautas diferentes a las que caracterizan a los grupos consolidados de la clase media alta: "El hecho es que ha aparecido una nueva clase media de gran pujanza pero de diferente sensibilidad a la identificada con lo blanco-cosmopolita-criollo, más cerca del mundo popular y más horizontal en su mundo de relacionarse con él, y no obstante, en creciente proximidad con los grupos consolidados". (Portocarrero, 1998: 21).

10 Esto lo ubica por el lado de las organizaciones o gremios, que se encuentran alrededor de la defensa de los pueblos ante la arremetida de las grandes trasnacionales mineras, y es allí donde se encuentra una movilización, que Montoya, le lleva a 
distintas y heterogéneas formas de analizar la identidad y cultura peruana.

\section{INTERPRETACIÓN CUALITATIVA DESDE EL QUANTUM EN ESTUDIO.}

Como analizamos en la presente exposición, son informantes de una Lima Norte ${ }^{11}$ que, desde los objetivos precisos de sus percepciones ponen énfasis a sus espacios en movimiento. Sea desde el negocio o los comercios, teniendo en cuenta siempre, la demanda de sus ventas, en confrontación con los grandes megamercados, pero no pensando en el sentido productivo de los insumos, sino en la búsqueda de trabajo en la "venta callejera" del comercio, como sentido de sobrevivencia. Es decir, de lo que se trata es de una movilidad de actores sociales, que a la vez moviliza geo-territorialmente una población que concentra dos millones trescientos mil habitantes en esta parte de Lima. No es lo que sucede en otras áreas de mercadeo transnacional donde el consumidor es ganado por dichas ofertas "megamercantiles" y termina rezagando a los micronegocios de las calles y a las casas - bodegas generando muchas veces la quiebra de los mismos. Tampoco se trata de un "milagro norteño" sino de una suerte de acumulación de sujetos sociales en movimiento que ganados por la oferta del "gran capital" llegan a convivir con ella, aceptándola y

señalar que: En el curso de la organización y la lucha, los dirigentes comuneros andinos descubrieron que la defensa de los recursos naturales debe ser, al mismo tiempo una defensa de las culturas, lenguas e identidades de los pueblos. (Montoya, 2010: 560)

11 Son 200 encuestados entrevistados entre los meses de agosto y setiembre del 2012, cuya característica central es ser vendedores en las calles aledañas a los centros comerciales. El trabajo de investigación tiene un carácter exploratorio descriptivo y analítico, debido a la forma en que se nos presentan los datos. Es una percepción demasiada endógena desde el punto de vista de los "ambulantes", no obstante, pensamos que las cifras son un soporte para sustentar una investigación bajo un análisis comparativo según el objetivo trazado en nuestro estudio. Tomamos como eje de referencia central el supermercado Metro, Plaza Vea, Roya Plaza y Megaplaza que se encuentran como vecinos contiguos, estableciendo así el área de investigación que lo ubicamos de la siguiente manera: Norte: Av. Los Alisos por la parte Norte del Metro (Independencia); Este: Av. Tupac Amaru (Tomás Unger). (Independencia); Oeste: Av. Las Palmeras y Manuel González Prada. (Los Olivos) y, Sur: Av. El Pacífico (Independencia) y Manuel Asencio Segura (Los Olivos). Es un trabajo de investigación correlato de un seguimiento que he venido realizando a los microempresarios en la misma zona. Ver: Jacinto Pazos, 2012. 
además incluyéndose en la misma oferta desde sus ventas, bajo estrategias que hacen posible reivindicar a sus "competidores" desde una desigual competencia y, con crisis o precarios capitales, pero pensándose como parte complementaria del consumo. En el fondo pueden ser parte de rubros de venta en completa transformación y cambio si de sobrevivencia se trata.

\section{REFERENCIAS DE LOS ACTORES SOCIALES EN EXPLORACIÓN.}

Los vendedores en la calle circunvecinales a los megamercados de Lima Norte tienen como lugar de nacimiento la provincia de Lima en un $43.0 \% \mathrm{y}$, el $57.0 \%$ tiene como lugar de nacimiento las provincias del país. Esto corrobora las estadísticas de anteriores encuestas realizadas ${ }^{12}$, es decir existe un margen que está entre el ocho y doce por ciento entre los vendedores provincianos y los limeños. Aún y con mucha más fuerza esto nos hace explicar que incluso, el nacido en Lima, no es el limeño tradicional o criollo capitalino, sino es un hijo de los migrantes que muchas veces está continuando el trabajo de los padres. Por eso es que muchos de ellos, en el trabajo de campo, nos referían, que en realidad si bien, son limeños también se sienten provincianos. En el fondo estamos todavía con los jóvenes "ambulantes" de segunda generación por esta zona que incluso, no parecen ser tanto de Lima. El rostro y el cabello se les presentan como un indicador de lo "provinciano" que manifiestan. Y lo más evidente de todo esto es su origen, ya que muchos de ellos dicen provenir de la Sierra y la Costa mientras una mínima proporción vienen de la Selva. Por sectores se observa que tanto en el sector producción como en servicio predominan los vendedores de provincias, en cambio, en el sector comercio existe cierto equilibrio. Hay que comprender que estamos refiriendo una mayoría de vendedores nacidos en Lima, cuyo sustento proviene de una familia exogámica o de matrimonio entre migrantes provincianos de orígenes distintos, los que se nos presentan en el estudio.

La mayoría de vendedores de la calle, residen en Independencia, Los Olivos y, Comas; por lo que el área de trabajo de los mismos vendedores está definida por la cercanía al gran centro comercial. Las calles adyacentes de dichos supermercados están invadidas por vendedores "ambulantes", bajo tiempos expresos, sobre todo a partir de las cuatro de la tarde en que los mismos toman por completo las veredas de las avenidas principales y de

12 Encuestas realizadas por el autor para los microempresarios en general en la misma área de estudio, el año 2005, 2007 y 2009. 
prioridad debajo del ovalo Izaguirre donde se dice, no los pueden desalojar porque dicho espacio le corresponde a la Municipalidad de Lima, por lo que los distritos contiguos no tienen autoridad al respecto. Y, por lo tanto, se puede decir es la zona de ambulantes por excelencia ${ }^{13}$. Se aprecia también, una ligera predominancia del sexo femenino sobre el masculino. Hay que destacar que dicha mayoría es consecuencia de las relaciones familiares que se dan en los espacios de los negocios y comercios, donde muchas veces se deja trabajando a la mujer, mientras el hombre se encuentra en los mismos menesteres pero en las zonas aledañas. Es decir, los esposos o convivientes, algunas veces ocupan puestos en lugares distintos, sin embargo puede suceder también que se concentren en un solo puesto de venta, pero donde el trabajo lleva a ubicarse por turnos, como observamos en varios de los "ambulantes" que se concentran por el frontis del Megaplaza, en la Av. Alfredo Mendiola. De ello no escapa, además, la preponderancia de la mujer o de las madres solteras que actualmente llevan sobre sus hombros la sobrevivencia familiar y que la estadísticas refieren como jefe del hogar ${ }^{14}$.

En el trabajo de campo etnográfico realizado, algunos vendedores decían no haber terminado los estudios de secundaria, por lo que muchos de ellos veían en la educación el punto de partida de una movilidad social permanente, y de la cual muchos, se lamentaban no haberlo logrado o porque habiendo tenido la oportunidad lo abandonaron. Esto se ve constantemente en las respuestas sobre el grado de instrucción que ellos tienen. Un vendedor en la calle, nos refirió que no tiene estudios básicos y que prácticamente es analfabeto, pero en la venta de frutas a la cual se dedicaba lograba fijar el peso y los vueltos o cambios del dinero que tenía que realizar. Como se observa es en la práctica donde comienzan a agilizar sus conocimientos pero por obligación. Hay que tener en cuenta que esta es la vía que han pasado gran parte de los microcomerciantes para forjarse como futuros emprendedores o microempresarios formales ${ }^{15}$. Y he allí

13 Los ubicados en las veredas del ovalo Izaguirre, fueron desalojados por el mes de agosto del 2013. Sin embargo, todas las noches o a partir de las cuatro de la tarde cuando los agentes de seguridad se retiran vuelven a invadir la zona. Esto sin contar la zona permanente de invasión en las calles adyacentes.

14 El idioma materno de los vendedores de la calle circunvecinales a los mega mercados de Lima Norte es en primer lugar el castellano con el $89.0 \%$ y le sigue el quechua con el $10.0 \%$. La tendencia se repite por sectores, la gran mayoría tiene como lengua materna el castellano.

15 La religión que más se profesa es la católica con el 77.5\% y la evangélica con el $10.0 \%$. El $6.5 \%$ se declara agnóstico, el $2.5 \%$ es cristiano y el $2.0 \%$ es 
la importancia de la educación sobre todo cuando vemos las relaciones mercantiles de los vendedores en el manejo de los créditos o, con la banca usurera, además de créditos financieros que muchas veces los puede dejar en la calle o embargados, por la falta de una formación educativa.

De manera general, los vendedores en la calle, se orientan en su mayoría por la venta de ropa, de comida, de golosinas y de Cds. En los contornos en las cuales se observan los "ambulantes", sobre todo en las vías principales o avenidas se hacen presentes vendedores de comidas de toda clase. Allí se encuentran por ejemplo, la venta de huevitos de codorniz, anticuchos, huevos y choclos o papas rellenas y, desde luego las bebidas calientes en tiempos de invierno, entre otras comidas. A los costados, los vendedores de polos, de zapatillas y hasta de frutas, o confiterías y gaseosas al paso. Lo que llama la atención en todo esto es que, existe bastante público consumidor para este tipo de productos. Una de las atracciones, son los precios que después de todo, son más baratos de los que expenden los centros comerciales. Es decir, no todos los que van a pasear por el lado de los malls, llegan a consumir en dichos recintos. Al revés encuentran un espacio para su comodidad económica y diversión alterna como paseante "al moderno vitrineo". Terminando muchos de éstos consumidores, en cualquiera de las carretillas de las ventas de comidas al aire libre. Y unas cosas adyacentes a todo ello, son las formas en que los clientes orientan sus conversaciones con sus vendedores. Muchas veces llegan al regateo de manera consensual que parece que estuvieran frente a una confrontación sin solución, pero donde muchas veces el vendedor se impone. Los vendedores de la calle, tienen una característica peculiar por este lado, juegan con la sensibilidad, con el discurso y además algo extraordinario, hasta con el paisanaje. No en vano las palabritas como "paisa", "joven" "señorita", "mamita", "papito", "doñita", juegan un papel fundamental en las relaciones interactivas del dialogo entre consumidores en la calle y estos ambulantes. Aunque se diga que de alguna forma se ha dejado de lado el "caserito" del siglo pasado, este sigue presente con otras características. Creo que eso es lo más significativo en este enfrentamiento entre los "grands malls" y los vendedores de la calle.

mormón. Se debe destacar que en el sector servicio, el 15.8\% profesa la religión evangélica y en el sector comercio el 10.6\%. 


\section{TABLA 1: REFERENCIAS GENERALES DE LOS ENCUESTADOS.}

\begin{tabular}{|c|c|}
\hline Concepto & Respuestas cuantitativas \\
\hline Lugar de nacimiento & Nacieron en Lima: $57.3 \%$ y $43.0 \%$ en provincias \\
\hline Región de origen & $\begin{array}{l}\text { En Lima y Callao: } 41.5 \% \text {. Costa (No Lima y Callao): } \\
18.0 \% \text {. Sierra: } 34.0 \% \text { y Selva: } 6.5 \%\end{array}$ \\
\hline Años en Lima & $\begin{array}{l}\text { Mayoría tiene menos de } 5 \text { años: } 38.5 \% \text {; entre } 6 \text { y } 10 \text { años: } \\
25.6 \% \text {; más de } 21 \text { años: } 18.8 \% \text {; de } 11 \text { a } 15 \text { años: } 12.0 \% \text {, } \\
\text { etc. }\end{array}$ \\
\hline $\begin{array}{l}\text { Lugar de residencia } \\
\text { actual }\end{array}$ & $\begin{array}{l}\text { Viven en Independencia: } 29.0 \% \text {; Los Olivos } 26.0 \% \text {; Co- } \\
\text { mas: } 9.0 \% \text {; SMP y Ventanilla se distribuyen el } 15.0 \% \text {. }\end{array}$ \\
\hline Sexo & $\begin{array}{l}\text { Predominan las mujeres con } 52.0 \% \text { y los varones con } \\
48.0 \% \text {. }\end{array}$ \\
\hline Grado de instrucción & $\begin{array}{l}\text { En mayoría secundaria completa: } 54.0 \% \text {; e incompleta: } \\
23.0 \% \text {; primaria ( o menos): } 14.0 \% \text {; la superior es casi } \\
\text { inexistente. }\end{array}$ \\
\hline Giro o rubro de venta & $\begin{array}{l}\text { Predominan: ropa: } 11.0 \% \text {; comida: } 9.5 \% \text {; golosinas: } \\
\text { 8.5\%; CDs: } 4.0 \% \text {; Accesorios celulares: } 4.0 \% \text {; Acceso- } \\
\text { rios de mujer: } 3.5 \% \text {; Teléfonos ambulantes: } 3.5 \% \text {; Pas- } \\
\text { teles: } 3.5 \% \text {; juguetes: } 3.5 \% \text {; yuca, frutas, huevos, anticu- } \\
\text { chos, cachangas, maíz: } 6.0 \% \text {. }\end{array}$ \\
\hline
\end{tabular}

Fuente: Encuesta socio-cultural, Agosto - setiembre: 2012.

Elaboración: Propia.

\section{LA IDENTIDAD COMO COMPLEJIDAD HISTÓRICA CULTURAL}

Varias interrogantes se abren en este acápite en la presente investigación: ¿Son las nociones de identidad, imaginarios urbanos y, la memoria popular suficiente para explicarnos fenómenos sociales recorridos por complejidades culturales-históricas tan acendradas, pero a la vez tan maleables? y, ¿Cómo se relaciona el discurso y el imaginario, en este escenario de identidades disímiles y heterogéneas, desde el "quantum" de los individuos dedicados al comercio en la calle, frente a una modernización dominante?, Planteo, estas interrogantes para entrar de pleno en el terreno antropológico en la presente investigación, tratando de reafirmar los límites con respecto a la versión economicista reduccionista cuantitativa por las que muchas veces se le ha investigado a este grupo social: los ambulantes o vendedores en la calle. Asumiendo solo cifras desde la economía y la mercadotecnia como es, en el caso último de Rolando Arellano y sus estilos de vida y consumo $(2002,2010)$. La identidad, los discursos y los 
imaginarios ubican necesariamente una serie de variables que las sociedades y las culturas van recreando desde hace muchos siglos atrás, a través de sus historias. No están lejos en ésta, el poder de dominación y el poder de la comunicación que desde sus distintas externalidades, los individuos recrean diariamente, sea desde los mismos ámbitos de la neo-colonización que el mundo del poder impone o también desde los grandes poderes sobre las cuales las comunicaciones y los lenguajes se rigen. La historia desde los individuos, registran lo imaginarios a su condición. Así como el discurso o la oralidad tiene presente la cotidianidad a su manera. Por lo tanto, hay que entender que el mundo en el que nos movemos es un nicho de imágenes, códigos, lenguajes orales y escritos. Además, de una infinidad de lenguas, idiomas, o diversas formas de entender la identidad. Nuestros imaginarios urbanos hacen y también construyen nuestra individualidad. Se presentan en ámbitos menos pensados. Pero resurgen al son de nuestra cotidianidad tanto como dominio o como parte de nuestra autonomía personal.

\section{LIMA REPRESENTA LA CIUDAD DE TODOS LOS PERUANOS.}

Un texto que generaliza al migrante peruano en la Capital, es el de Matos Mar (2012). Sostiene que Lima, se ha erigido desde la diversidad étnica cultural del país, y que su horizonte obedece a rasgos culturales andinos que se reproducen en la ciudad. Esto se universaliza para el país y, en sí, la proposición de la integración de una sociedad nacional en ciernes cuyas características principales aún el Estado la pasa desapercibido ${ }^{16}$. Naturalmente, Lima no es el Perú, aún tenemos bolsones regionales en el país con una fuerte crisis económica, que hace lento o retrocede dicho proceso y, desde luego, su fractura y fragmentación sostenida desde los conflictos medio-ambientales y ecológicos que hoy observamos en varias provincias de la sierra y amazonia del país. En sí, es el capitalismo transnacional que por su carácter expresan su causa y efecto.

$\mathrm{Si}$ observamos, las respuestas que consideran en gran porcentaje que, Lima sí representa la ciudad de todos los peruanos, nos hace explicar las orientaciones socio-culturales hacia la cual se dirige la Capital. Si bien esto hay que entenderlo desde una subjetividad colectiva -de acuerdo a las encuestas-, aquí se mueven los hilos de la historia desde un punto matriz de arribo como emigrantes. Es decir, Lima, como la ciudad en consolidación desde dicha idea trata de mirar a los hijos como los que reprocesan el lugar de nacimiento, bajo una forma de identidad peculiar, visibilizada a su manera, 
donde la niñez y la juventud, más las formas de trabajo se han logrado establecer y casi asegurarse a pesar de su precariedad. Entonces, Lima, imaginada y vivida como el gran ogro, expoliador y discriminador racial que sufrieron los abuelos de esta generación, se presenta hoy, desde esta versión ya bajo determinado espacio, como "tolerante" y "comprensiva", Lo que los hace seguir en carrera de supervivencia. Esto explica de alguna forma que los nuevos limeños que venden en la calle, o mejor explicado, los padres y los hijos de los migrantes provincianos, ya no ven a Lima y a los limeños oriundos criollos, como los típicos posesionarios de la Capital como ciudad, sino que la observan como un espacio más abierto, a pesar de algún reducido grupo de pobladores que se cree dueño de los espacios públicos, que incluso la han subjetivado y concretizado con grandes cercos perimétricos de hierro que en muchos casos bien puede valer pensar en su racialidad y racismo soterrado y propuesto a su manera. Que no es sino su estatus y prestigio económico que se piensa perder frente al migrante de clase media popular, antes que su racismo resultante.

Desde luego, que esto se supera vigorizando su conquista con demandas al Estado o a los municipios, pero a la vez tratando de imponerse sosegadamente pensando siempre que, los migrantes de la primera generación fueron los primeros forjadores y constructores de esta ciudad. Y lo más lógico, dentro de esta idea es precisamente, porque el trabajo se pone por delante para pensar en la ciudad como incluyente de las necesidades apremiantes y de sobrevivencia de los ambulantes e incluso de los actuales limeños, hijos de migrantes. Esto genera en sí procesos identitarios, que conllevan a explicar no sentidos de pertenencia en su sentido histórico tradicional como se observaban en las antiguas comunidades, sino sentidos de movilidad social y relaciones de horizontalidad dentro de una interculturalidad exogámica permanente en la Capital. Lo que en algún momento, el siglo pasado les fue adverso, debido a la discriminación racial que se observaba de manera rígida.

Precisamente llaman la atención, dos frases claves: "Lima como ciudad de todos los peruanos", y hay, "oportunidades para todos". En el fondo, la oportunidad implica trabajo, que si bien es precario o marginal y hasta de bajos salarios, no quiere decir que estén excluidos de lo poco que les puede ofrecer la Capital. Y esto necesita de una gran reflexión, ya que frente a lo que tienen como producción y como trabajo en las provincias originarias de los padres, que en realidad es cuasi nulo, se puede suponer ya decididamente que nuestros sujetos en investigación, se 
encuentran partícipes del banquete de la "capital neo-criolla" y, solamente se trata de enfrentarlo y de desafiarlo en cualquier frente. Como se sabe, lo que atormenta a los citadinos de toda gran ciudad es: su "afeamiento" e "invasión" de espacios y calles por estos "foráneos ambulantes". Y por extensión, su anomia, "lumpenización" y delincuencia que ello genera. No en vano algunos "oficialistas criollos" proclamaron en su momento, no dejar entrar más a Lima, en sus espacios concéntricos a, los provincianos migrantes porque la estaban atiborrando de barriadas y de "ambulantes" que, en cualquier momento podrían tomarla por completo. Incluso desde lo político-subversivo. Esto fue, lo que tenía en la cabeza, esta gente de los años sesenta y setenta del siglo pasado, que hasta se llegaron a crear fortines para enfrentarlos en caso de rebelión popular ${ }^{17}$. Pero la práctica comercial en la calle, no es gratuita y tampoco puede ser porque quienes la realizan no la conozcan. Al revés la vida cotidiana en el mundo rural o distrital provinciano ha pasado por un fuerte intercambio comercial, ya desde el siglo pasado. Y aún, se debe de leer históricamente, así podemos decir que el vendedor ambulante ha tenido su fuerza durante gran parte de los inicios de nuestra vida colonial y se consolidó con los inicios de la República ${ }^{18}$. Por ello, debemos de leer en las cifras, que siempre los mercados de abastos o las ferias campesinas, han pasado por esa venta primigenia de la invasión de las calles y no es casualidad que el sentido de sobrevivencia de éstos pobladores pase por este lado tolerable de oportunidades en las que se encuentran actualmente en la ciudad.

Esto no quiere decir que en sectores privilegiados de la Capital no exista además de la intolerancia, la discriminación en sus distintas formas. Esto se observa diariamente. Incluso tenemos denuncias en la televisión peruana de manera continua ${ }^{19}$. Aquí hay que ver cómo se expresan los espacios concéntricos de la Capital, además de sus expresiones multicéntricas en las cuales se encuentra inmersa. Por supuesto que, no podemos

17 Versión de Max Meneses y José Matos Mar, sobre la creación de los fortines en los extremos de la ciudad de Lima. No es casual los fortines La Pólvora, Rímac y Carabayllo, etc. (Conversación con los mismos: Enero, 2013)

18 Ver: Iwasaki, 1988.

19 Allá por el mes de febrero del 2012, dentro de varios casos, los medios de comunicación entregaron la noticia de que el hijo de una actriz de televisión (Celine Aguirre) y de un cantante muy reconocidos en los ámbitos de música rock y afroperuana (Micky Gonzales), agredió "racistamente" a una señora en un centro comercial de la clase media alta limeña. (Ver, los diarios y medios electrónicos de la época). 
explicar la discriminación a la europea, menos a la estadounidense por su legitimación-legalidad de su época. Y menos por la epidermis de la piel. Las características de lo blanco y lo negro, o lo indio no tienen que asimilarse a lo que vemos en los centros mundiales desde sus históricas relaciones sociales y raciales por las cuales se manifiestan hasta la actualidad. Pero hay que entender, que en la subjetividad del mundo dominante la intolerancia prevalece. Y la segregación cobra sus visos antes que por lo racista, por la posición económica, pero donde su impronta cobra espacios de discriminación, por origen étnico-cultural. A pesar que en la encuesta por extrema minoría consideran que, Lima no representa la ciudad de todos los peruanos. Porque, según refieren, no representa a todos y además existe discriminación y, desigualdad. Lo que es muy nimio como estadístico. Algo que llama sumamente la atención, porque parecen cargar a la subjetividad lo evidente, tratando de ocultar u olvidar lo que muchas veces llevaron como escarnio los abuelos y los padres pero que a estas alturas no se quiere reconocer su existencia. Tal vez la lógica venga por el lado de pensar en una sociedad o población más integrada, pero volviéndose cómplice bajo el escondite, de uno de los vicios más permisibles de la sociedad peruana. Juega en parte el temor, el desconocimiento o la sumisión histórica que ha recorrido el país. A veces un "todas las sangres" forzado por las coyunturas y circunstancias, del cual los políticos buscan sus mayores réditos. Sea como utilización o como propuesta discursiva. En realidad, buscando horizontalidad, respeto e inclusión, pero simulando y ocultando el conflicto racial.

\section{ENTREELNEGOCIO, EL TRABAJOY LAS OPORTUNIDADES.}

La categoría identidad tiene aristas múltiples que no solo se refieren a la subjetividad, el conflicto o la historia como tal, sino a la situación concreta de los individuos, en lugares o recintos específicos en los cuales manifiestan sus relaciones laborales. La noción relaciones de trabajo implica una función o un rol en términos de Castells (2002), sin embargo, en el caso de sobrevivencia y de cambio aquí parece jugar un papel decisivo en la subjetividad de las personas. Entonces, al margen de lo que sucedió en otras partes del mundo, en Lima la identidad se construye y se consolida, pero desde nuevas expresiones que hacen de Lima generar nuevos espacios en función al trabajo. Por lo tanto, se recorre lo que se podría denominar un concepto que va más allá de las relaciones conflictuales de los individuos, sea por origen o territorio, y más bien se ancla a un espacio que implica la sobrevivencia, en este caso el negocio de la calle. Quizás si observamos 
detenidamente, no solo se trata de la "realización de los negocios en Lima", sino que a la vez, se reitera diciendo, "aquí encontré trabajo", lo cual no está lejos de lo anteriormente expuesto en significado, sumando ambos más del 42.0\%. Pero donde además: "aquí nací y me siento orgulloso" (20.0\%) y "aqui nacieron mis hijos" (11.0\%). Mientras una minoría deja de lado su identificación. En el fondo, los cambios radicales de la ciudad, más el nacimiento de las nuevas generaciones hacen de Lima, una nueva mirada y una forma de apreciarlo desde estas perspectivas. Queremos se tenga en cuenta, que si bien el trabajo implica expresiones materiales de sobrevivencia, no se puede pensarlo como un rol o una función que cumplen los individuos dentro de este espacio, sino cómo los individuos expresan a la vez, nuevas resemantizaciones y resignificados, de lo que fue en un primer momento lo extraño de la ciudad a su sentir.

Cuando se observa que, Lima simboliza el Perú entero, la Capital se convierte en la centralidad subjetiva de la visión de los vendedores de la calle. En sí, el multiculturalismo, además de las manifestaciones interculturales de encuentro y de vecindad en la venta que, hacen mirar ya no los sentidos expresivos históricos de la cual fueron originarios sino de mirar a pobladores que se hacen presente de distintas ciudades e, incluso de los nietos de los migrantes que ya se ven completamente distintos a lo que fueron sus abuelos. Y lo más resaltante, dentro de todo esto, es que en un segundo momento entra a tallar la idea de simbolizar a Lima como el "empresariado provinciano y limeño", dejando de lado, la frase de que representa a "los cholos peruanos", el cual como minoría ínfima, en este grupo de personas encuestadas excluye el sentido de la "etnicidad" o lo "originario", para nuevamente poner por delante los sentidos de oportunidad $o$, "donde encontré trabajo" que se les presentó desde el momento de su arribo.

Desde este camino tenemos espacios, de una inter-pluri-culturalidad que hacen que la Capital al margen, de quienes lo suponían suya, "exclusiva o neo-acriollada", tienen que entender, que los espacios de tolerancia parece ser de quienes fueron agredidos racialmente y que, hoy se observan comprensivos ante todo. Y otra cosa: la gran cantidad de nuevos limeños que excluyen en este mundo, el origen de los padres por más que ellos tengan procedencia serrana, costeña o amazónica para pensar una Lima de todos los peruanos, pueden ser las razones de ello aparte de las oportunidades, porque es la Capital del país y, todos migran a Lima, lo que es un gran peso en la versiones recopiladas etnográficamente. Debemos 
de entender que, estamos en una transculturalidad existente vista a diario, donde los lazos de endogamia originales de padres o abuelos han dado lugar a redes de convivencia y de matrimonio rotundamente exogámicos, mucho más heterogéneo y pluricultural. No se trata solo de la pluralidad de orígenes en un pequeño ámbito, sino expresa que tengamos hermanos, tíos o amigos, cuyas procedencias completamente distintas los tengamos que ver en lazos de matrimonios o convivencias exogámicas, que hacen en ellos responderse, las mismas preguntas de siempre: ¿de dónde son tus padres? $y$, de ¿dónde es tu madre? Y finalmente, ¿de dónde son tus abuelos? Si en caso los hijos han nacido en Lima. Se tiene respuesta de padres inter-regionales, o inter-costaserramazónicos, que los descendientes se encuentran en ciertas disyuntivas de su acercamiento a uno u otro lugar, del origen de sus progenitores. En realidad, la complejidad de sentirse limeño y de expresarlo es desterrando la figura de ambos, pero a pesar de todo, siempre sale a relucir el origen de uno de ellos como su preferencia u inclinación que se puede decir, buena parte de los hijos de los migrantes siempre tienden a visitar como los pueblos de los padres ${ }^{20}$.

Es decir, en el seno de la familia y en todos los estratos sociales está naciendo una forma de ver Lima, distinta y no pensándolo ajena, a lo que se supone puede ser mirada por no haber nacido en esta ciudad o por el lugar de origen de nuestros padres o abuelos. Al contrario parece que desde las lógicas de los "ambulantes" se ven otras expresiones al respecto. Y ello se corrobora cuando en la misma encuesta se reivindica Lima como origen con más convicción, cuando se responde, sin pensarse en orígenes e identidades previas o de los mismos padres, cuando refieren, aquí nací y me siento orgulloso y aquí nacieron mis hijos.

20 En conversaciones de manera espontánea preguntamos a los estudiantes de la Universidad Ricardo Palma y San Marcos durante la última década: ¿De dónde son tus padres?, podríamos decir que una gran mayoría nos responde que son de provincias. Todos ellos se inclinan por ambos: los pueblos del papá o de la mamá. Pero se nota que siempre el que prima en conocerse primero es el pueblo del papá y casi todos siempre han viajado al pueblo de uno u otro, salvo contadas excepciones. Notas sobre Lima (PJ). 
TABLA 2: REPRESENTATIVIDAD LIMEÑA

\begin{tabular}{|c|c|}
\hline Concepto & Referencias cuantitativas. \\
\hline $\begin{array}{l}\text { Lima, ciudad de } \\
\text { todos los peruanos. }\end{array}$ & $\begin{array}{l}\text { Mayoría dice que Lima es la ciudad que representa a to- } \\
\text { dos los peruanos: } 71.0 \% \text {. Porque: Hay oportunidades para } \\
\text { todos: } 20.0 \% \text {; Es la Capital: } 17.0 \% \text {; Todos vienen a Lima: } \\
16.3 \% \text {; Hay de todo en Lima: } 11.1 \% \text {; Es poli-racial: } 7.4 \% \text {; } \\
\text { Hay trabajo: } 5.9 \% \text {; Por Identidad: } 3.7 \% \text {, etc. En Minoría: } \\
29.0 \% \text {. Lima no representa: Porque es capital no representa } \\
\text { a todos: } 27.6 \% \text {; Hay discriminación: } 13.8 \% \text {; Hay desigual- } \\
\text { dad, } 6.9 \% \text {, No hay oportunidades para todos: } 6.9 \% \text {, etc. }\end{array}$ \\
\hline Identidad con Lima & $\begin{array}{l}\text { Porque: Aquí hice mi negocio: } 25.5 \% \text {; Aquí nací y me siento } \\
\text { orgulloso: } 20.0 \% \text {; No me identifico: } 17.5 \% \text {; Aquí encontré } \\
\text { trabajo: } 17.0 \% \text {, Aquí nacieron mis hijos: } 11.0 \% \text {; Aquí hice } \\
\text { mi dinero: } 2.5 \% \text {; Aquí nací y no cambio: } 2.0 \% \text {. }\end{array}$ \\
\hline Lima simboliza: & $\begin{array}{l}\text { El Perú entero: } 30.7 \% \text {; Al empresariado limeño y provin- } \\
\text { ciano: } 19.1 \% \text {; Al mundo criollo limeño: } 12.1 \% \text {; A los pro- } \\
\text { vincianos del Perú: } 9.5 \% \text {; No representa nada: } 8.0 \% \text {; A los } \\
\text { cholos peruanos } 6.0 \% \text {; Al empresario provinciano: } 6.0 \% \text {, Al } \\
\text { empresario limeño: } 5.0 \% \text {, etc. }\end{array}$ \\
\hline $\begin{array}{l}\text { Lima es una } \\
\text { ciudad: }\end{array}$ & $\begin{array}{l}\text { Donde encontré trabajo: } 52.8 \% \text {, Donde se puede trabajar } \\
\text { solo para sobrevivir: } 28.6 \% \text {; Donde hice dinero: } 7.5 \% \text {; No } \\
\text { representa nada: } 3.0 \% \text {, Donde nunca hay trabajo: } 2.0 \% \text {, etc. }\end{array}$ \\
\hline
\end{tabular}

Fuente: Encuesta socio-cultural, Agosto - setiembre: 2012.

Elaboración: Propia.

Lo que ubicamos desde las estadísticas, es una Lima que cobra nuevos visos para entenderlo, ya que es una reivindicación donde se dice que ésta, simboliza y representa, al Perú entero, es decir, estamos ante un cambio de imaginario, que las mismas generaciones presentes y venideras se encargan de reivindicar logrando mantenerse al margen del epíteto endilgado, de que los migrantes son los que han hecho de Lima, una ciudad conquistada, sucia, maloliente y pestilente con la cual se carga al mundo migrante la negatividad limeña. O también lo "racista, discriminatorio y excluyente" que para esta Lima Norte, se siente en retirada. Algo hace pensar en las nuevas formas de observar a esta ciudad, fuera de los antiguos parámetros sociales y culturales establecidos. Desde luego, resalta otra pregunta, frente a la discriminación étnica-racial que se ha contemplado en la subjetividad por muchos años, ¿no será mejor ocultarse en sus primigenios territorios ocupados auto-arrinconándose y rechazándose de los sectores pudientes neo-acriollados para sentirse a la vez exclusivos de dichos lugares, pero a la vez, incluidos en la ciudad capital? Las cifras llevan a explicar un 
sentido micro-específico, pero la etnografía, nos lleva a reivindicar que se juegan dos momentos. Uno de los que se sienten propios del lugar, como son los que compraron el terreno o la invadieron. Y, dos, la de los hijos y nietos que refieren salir de "estos lugares" para irse a espacios mediosaltos. Es aquí donde entra la colisión y los que supuestamente dejaron su sangre, sudor y lágrimas, en este caso los abuelos -como ellos mismos lo dicen $^{21}$-, jamás se irán de estos espacios porque conocieron del racismo a su manera con gran dolor. Mientras los hijos y nietos se les hace ligero señalar su movilidad social a secas e irse a vivir por los sectores pudientes. Incluso obligando permanentemente a los padres.

\section{LIMA COMO RECINTO DE TODAS LAS SANGRES}

La metáfora de "todas las sangres" se reivindica en distintos ámbitos de la sociedad peruana cuando de encuentros o de sensibilidades se trata. Implica a la vez las distintas formas culturales que se presentan bajo los sentidos diversos que se presentan. Arguedas autor de la frase, desarrolla la idea bajo personajes disimiles donde no solo se trata de individuos en conflicto permanente sino bajo una mirada donde se articulan lenguas y rostros de todo tipo como parte del desarrollo de la sociedad peruana. En sí una alegoría, entre los grupos étnicos que desde la diversidad pueden generar diálogos y entendimientos no solo culturales, sino políticos y en última instancia étnicas ${ }^{22}$. No obstante, tener presente que es válida desde el discurso, pero también define o deja en el subterráneo una desigualdad social extrema que en realidad, es el detonante de violencias y conflictos pero que, muchas veces no se quiere mirar. $\mathrm{O}$ en todo caso denostar desde el centralismo limeño como lo pernicioso y subversivo. Es curioso pero todo lo "revoltoso" es regional o provinciano. Lo relacionamos porque la frase que consideran propicia los "ambulantes" y que sale a relucir en la encuesta dice que: Lima representa Todas las sangres (41.0\%) La frase, se presenta como una consigna que llevan en mente desde un sentido positivo, tratando de advertirnos, la "cara optimista" de la sociedad, donde la dicotomización "étnica" se excluye enfáticamente desde una lógica positiva de la expresión poniendo como contrapartida la idea de superación donde se antepone una subjetividad integradora a su manera. Algo sale a relucir en esta idea, pues,

21 Ver mi tesis: Jacinto Pazos, 2012.

22 Ver: José María Arguedas (1988). Todas las Sangres. Lima: Horizonte. (Recordemos a los hermanos Aragón de Peralta y su lucha diaria en búsqueda de mundos, desde estructuras sociales distintas, donde al final no queda sino pensar en la comunión para lograr el cambio). 
la contrapartida de saberse en sus lugares de origen con una desventaja en servicios de todo tipo y más aún en trabajo, al margen de la sobrevivencia de lo que se observa en la centralidad limeña, ésta es menos perniciosa que la del lugar de nacimiento, incluso con la pobreza a cuestas. Y lo curioso es, que aquí no funciona la idea de que, los cholos progresan en Lima $(17.0 \%)$, que esta vez no es la reivindicación por los sujetos en estudio. La relegan totalmente, por lo que aquí ubicamos una gran diferencia con lo que encontramos en el mismo espacio de investigación, pero para los microempresarios en conjunto (incluyendo vendedores en la calle), durante anteriores de trabajo de campo, que era la frase más reivindicada por los mismos. Una hipótesis primigenia, es que primaban un universo de rubros o giros de ventas que implicaban bodegas, tiendas de abarrotes, salones de belleza, restaurantes, servicios profesionales, etc. Que es donde la racionalidad trastoca su especificidad y da lugar a un cosmos mucho más amplio, que bien puede ser lo alto-medio popular frente a lo pobremedio popular. No es que se relegue la opinión, sino el conjunto también marca un derrotero y explica su orientación, cuyo común denominador es precisamente enfrentarse a grandes megamercados limeños ${ }^{23}$. Y de eso trataba las encuestas precedentes.

Si bien, en un segundo momento dicen, Ninguna frase representa a Lima (23.0\%), como enunciado extremo. Aún, desde esta lógica parece establecerse la idea de convergencia, que tanto se resalta en la frase "Todas las sangres" y la palabra, "cholo" no se le asocia con el progreso quizás, porque el ser ambulante en la calle es el primer piso de toda una trayectoria de esfuerzo y trabajo, aún no realizado en los bienes materiales de existencia primordiales para sobrevivir decentemente. El trabajo precario, el alquiler de un cuarto-dormitorio, o el desplazamiento a zonas barriales donde parten de cero bajo un invadido frágil terreno, la educación de los hijos que se cruza en la lógica común del progreso, y su pérdida de privilegios en este servicio con respecto a las zonas que algún momento conocieron, como parte de sus juventud educada. Por esto, es que es segura y sin duda la respuesta. Un cholo no progresa en Lima, si se ve como ambulante. Y la frase le es propicia. En realidad, ellos sí ven el duro trabajo de irrumpir en las afueras de estos megamercados sobre las cuales laboran.

Pero en todas estas respuestas, prácticamente se le excluye su orientación racial para subrayar anulando -nuevamente en esta encuesta-

23 Ibid. Jacinto, 2012. 
la frase de que los pitucos son racistas y los criollos son ociosos, que los encuestados lo expresan en una absoluta minoría ${ }^{24}$. En realidad, se están perdiendo las nociones que de alguna manera hacían ver el país de distinta forma o dividida cuasi estamentalmente bajo dicha racionalidad, si nos enfocamos por los designios al azar de estos individuos desde sus respuestas. Tenemos entonces, otras perspectivas de la sociedad limeña dentro de todos los antagonismos que se les presentan. Es quizás, por eso que aquellos que sostienen que Lima no representa nada porque "no representa a todos", "existe discriminación" y "hay desigualdad"; es una minoría huérfana de argumentos por describirlo menos. Y también, que fueron "discriminados por el color de su piel", es una minoría la que sostiene esta idea ${ }^{25}$, no obstante la observamos una cifra considerable por este lado. Una denotación que se puede explicar por lograr un espacio que ya no necesariamente, pasaba por interrelacionarse con los primeros interlocutores de sus abuelos, y por una generación que ya produce una cultura urbana más incrustada en áreas antes restringidas.

Y más bien, lo que vuelve a sobresalir es el significado de la palabra "cholo", como referente nuevamente de que expresa "lo peruano", de manera mucho más plural o más multicultural o más genérico para la sociedad nuestra. Es importante esta imagen ya que no solo se trata de una demanda sino, de la preocupación por una identidad que a pesar de su estigma, bajo un discurso racista subjetivado, cobra espacios en los sectores de nuevos limeños populares, incluso bajo expresiones de trabajos de sobrevivencia. Da la impresión, de observar categorías ambiguas que se dejan de lado en determinado momento para reivindicarse en otro, más con la versión donde lo cholo como significado de lo provinciano queda completamente relegada a un segundo plano, y más bien la palabra "serrano", parece funcionar como el "orgullo provinciano", en su mayoría para los encuestados y, no como orgullo del Perú o nacional que se quedan en minoría frente a la primera respuesta. Esto nos podría explicar, en sí el lado regional que se le ha endilgado a la misma palabra

24 Ver el libro de Golte y Adams (Ibid, 1987) y el de Adams y Valdivia (Ibid, 1991).

25 El 37.0\% de vendedores de la calle circunvecinales a los megamercados de Lima Norte sí se ha sentido discriminado en Lima, tanto por el color de su piel como por su raza y el $63.0 \%$ no se ha sentido discriminado. Por sectores, sólo el $37.9 \%$ en el sector producción, el $36.8 \%$ en el sector servicio y el $37.0 \%$ en el sector comercio se ha sentido discriminado alguna vez por el color de su piel o raza. 
y por la cual no tenemos que lograr mayor argumento en su denotación ${ }^{26}$. Tampoco se trata de pensar en la subjetividad, como percepción lineal de nuestros actos o comportamientos donde se dejan de lado en la vida cotidiana las manifestaciones raciales y racistas de la sociedad limeña. Ella está bien marcada en espacios capitalinos definidos, que hace diariamente su evidencia, lo cual no prescinde de espacios sociales donde la ciudad se le mira de distinta manera o mucha más tolerante y consensual.

\section{ESPACIOS SIMBÓLICOS COMO REFERENTES DE IDENTIDAD LIMEÑA.}

Portocarrero y Komadina (2001), explican que, la subjetividad debe ser entendida como el espacio donde se articulan lo biológico-pulsional y lo simbólico, el lugar en el que se entreteje lo social y lo personal, donde se define la individualidad ${ }^{27}$. La pregunta que se observa de inmediato: ¿cómo se relaciona la subjetividad, lo simbólico con los espacios urbanos históricos limeños? Una de las menciones importantes en parte de este discurso-investigación es la mirada de Armando Silva cuando escribe:

Las percepciones ciudadanas que responden a los centros de nuestras ciudades del continente como hecho de cultura pueden seguir sin fin. Verdaderos o falsos no importa. Se construyen en la memoria ciudadano como ciertos. Rigen comportamientos sociales, identifican comunidades, generan batallas entre seguidores de las mismas causas, vislumbran el futuro. Poseen en común que son fantasías ciudadanas nacidas al calor de la fricción social y poco a poco se convierten en hecho público. La ciudad desde estas visiones pasa a ser un efecto imaginario de sus ciudadanos. Por ello los distintos caminos para dibujar esos mapas de afecto ciudadanos han de orientarse

26 En parte, los entrevistados microempresarios, residentes en la zona, nos decían que jamás se retirarían del lugar porque en otros lugares serían discriminados racial y socialmente. (Ver: Jacinto, 2012. Capítulo X, y Anexo 5).

27 Continúan, que: "En efecto, la subjetividad es organizada por la cultura en la medida que las significaciones sociales permiten una regulación viable de la impulsividad. Es decir, la cultura encuentra restricciones en lo real de lo afectivo. No se trata, entonces, de un sistema simbólico omnipotente y de una interioridad absolutamente maleable. Los sentidos sociales sin impulsividad son tan impensables como una vida sin metas ni normas. Tanto la cultura como la subjetividad, deben ser concebidas como realidades complejas y heterogéneas cuya dinámica está atravesada por la acomodación, la tensión y el conflicto". (Portocarrero y Komadina, 2001: 15). 
hacia su captación emocional. Si un sujeto siente un olor inexistente es interés de la psicología individual, pero si la fantástica sensación es colectiva, rebasa las fronteras íntimas y entra en el campo de las culturas ciudadanas: sus imaginarios urbanos. (Silva, 2009, p. 158).

Lo importante y, que va de la mano con la respuesta, es que no se deja de reivindicar a Lima en sus monumentos históricos o desde los más representativos que encuentra u observa. Así, por ejemplo, el monumento de mayor identificación es la Plaza Mayor, el Palacio de gobierno y luego la Catedral, quizás los espacios de mayor relevancia de los limeños que por ese lado se encuentran. Ojo, que hay que tener en cuenta, que son espacios cercanos, los tienen a la mano casi ya provincianísima o peruanizada. Para seguir en sus lógicas, podemos decir que, cuasi lo tienen como suyo, y además es el recorrido de entrada que se hacen o hacían los primeros migrantes a la Capital ${ }^{28}$, siempre como el lugar de encuentro de amigos, paisanos o familiares para luego enrumbar a sus sitios de reunión festiva en sus primeros años cuando la casa era de los parientes o no lo tenían; sino en sus habitaciones alquilados que muchas veces tenían que abandonar por su incomodidad. Ello se ve también cuando resaltan nuevamente la reivindicación de Lima a partir de sus templos religiosos que nuevamente pasa por la Catedral y cuya historia limeña se simboliza por el lado de la época colonial. Es decir, si miramos las cifras, lo que se tiene como representatividad limeña son los símbolos que de alguna manera se pueden caracterizar como tradicionales.

Y si lo vemos por el lado subjetivo con respecto a la Catedral de Lima, para la mayoría sigue representando la tradición religiosa de los peruanos y la tradición religiosa de los limeños, coincidiendo así, con las investigaciones que hemos realizado últimamente a un grupo de microempresarios ${ }^{29}$. Ya antes mencionado. Es decir, algo que se reclama, es esta relación de lo peruano y lo limeño desde el ángulo religioso, lo que nos lleva a explicar el sentido de integración que tiene la religión católica, pero a la vez también su expresión de dominio o fuerza que ha tenido el catolicismo desde los inicios

28 Me contaban unos ancianos [Doña Victoria Bardales (80) y don Luis Bardales (85)] que sus primeras miradas a la Capital, lo realizaron por el Parque Universitario y la Plaza San Martín, tratando de ubicarse luego por la Catedral de Lima. No están lejos de la percepción que demuestran los micro-comerciantes acerca de dichos lugares aún muy latentes en sus recuerdos después de muchos años.

29 Ver: Jacinto Pazos, 2012. 
de la colonización en el país. Esto no exime, ver el mundo migrante en su arribo a la Capital observando la Catedral como espacio de redención, donde se enunciaron sus primeros paseos, y posiblemente sus primeras fotos con una capital aún desconocida, y además sus primeras reuniones de amigos y amigas. Una minoría lo ve por el lado de la tradición religiosa de limeños, lo que es muy ínfimo. Por lo que se puede decir, que a pesar de esto continúan las lógicas de un Perú diverso, heterogéneo, bajo una Lima demasiada porosa que el mundo migrante, sus hijos y sus nietos reconstruyen y reifican bajo enormes desigualdades sociales que pueden admitir a su manera. Desde luego, es desde el aspecto religioso, donde se puede ver ese tipo de identificaciones, falta observarlo de manera completa desde las lógicas del mercado $\mathrm{y}$, de las relaciones de trabajo como sentido incluyente o excluyente desde los negocios o comercios a los cuales se dedica.

\section{TABLA 3: PATRIMONIO MONUMENTAL - HISTORICO REPRESENTATIVO}

\begin{tabular}{|c|c|}
\hline CONCEPTO & REFERENCIAS CUANTITATIVAS \\
\hline $\begin{array}{l}\text { Frase propicia para } \\
\text { Lima: }\end{array}$ & $\begin{array}{l}\text { Todas las sangres: } 41.0 \% \text {; Ninguna frase representa a Lima: } \\
23.0 \% \text {; } \\
\text { Los cholos progresan en Lima: } 17.0 \% \text {; La flor de la canela: } 9.0 \% \text {; } \\
\text { Los pituquitos son racistas: } 7.0 \% \text {; Los criollos son ociosos: } 3.0 \% \text {. }\end{array}$ \\
\hline $\begin{array}{l}\text { Centro representati- } \\
\text { vo de Lima }\end{array}$ & $\begin{array}{l}\text { La Plaza Mayor (45.4); El palacio de Gobierno: (19.4); La } \\
\text { Catedral de Lima: (15.8); El parque Universitario: (10.2); } \\
\text { Villa El salvador: (2.6); Ninguno: (1.5); Todos los parques, } \\
\text { plazas y monumentos: (1.0); Parque de las Leyendas: (1.0); } \\
\text { La Molina; Barranco; Plaza San Martín: c/u: 0.5\%, etc. }\end{array}$ \\
\hline $\begin{array}{l}\text { La Catedral de Lima } \\
\text { representa: }\end{array}$ & $\begin{array}{l}\text { La tradición religiosa de los peruanos: 54.8; La tradición } \\
\text { religiosa de los limeños: 19.6; La tradición religiosa de los } \\
\text { limeños y provincianos: 15.6; No significa ninguna tradi- } \\
\text { ción: 6.5; La tradición religiosa de los provincianos: } 3.5 \% \text {. }\end{array}$ \\
\hline $\begin{array}{l}\text { El Centro Histórico } \\
\text { representa: }\end{array}$ & $\begin{array}{l}\text { Lima tradicional: } 50.0 \% \text {; Lima de todos los peruanos: } 26.8 \% \text {; } \\
\text { Lima moderna: } 7.1 \% \text {; Lima colonial: } 7.1 \% \text {; Lima de los mi- } \\
\text { grantes: } 4.0 \% \text {; El centro del país: } 3.0 \% \text {; Lima señorial: } 0.5 \text {; No } \\
\text { conoce el Centro Histórico: } 0.5 \% \text {; No representa nada: } 0.5 \% \text {. }\end{array}$ \\
\hline $\begin{array}{l}\text { Discriminación ra- } \\
\text { cial en Lima }\end{array}$ & Nunca: $63.0 \%$ y Sí: $37 \%$. \\
\hline $\begin{array}{l}\text { Significado de lo } \\
\text { "cholo" }\end{array}$ & $\begin{array}{l}\text { Ser peruano: } 58.6 \% \text {; Ser provinciano: } 27.3 \% \text {; Ser Serrano: } \\
\text { 7.1\%, Nada: } 5.6 \% \text {; Ser limeño: } 1.5 \% \text {. }\end{array}$ \\
\hline $\begin{array}{lll}\text { Significado } & \text { de } & \text { lo } \\
\text { "Serrano." } & & \end{array}$ & $\begin{array}{l}\text { Orgullo provinciano: } 39.4 \% \text {; Orgullo del Perú: } 26.3 \% \text {; Or- } \\
\text { gullo nacional: } 25.8 \% \text {, No significa nada: } 5.1 \% \text {. }\end{array}$ \\
\hline
\end{tabular}

Fuente: Encuesta socio-cultural, Agosto - setiembre: 2012.

Elaboración: Propia. 


\section{REFLEXIONES PRELIMINARES: ENTRE LA IDENTIDAD Y LOS IMAGINARIOS URBANOS LIMEÑOS.}

Reconocemos en Castells $(2002)^{30}$, sus formas de expresar los sentidos de identidad, bajo la orientación de una identidad-proyecto donde el actor social en movimiento se impone y trastoca las estructuras espaciales en el tiempo, precipitando a la vez, las relaciones sociales verticales impositivas que le atan a regímenes de exclusión. En este sentido la identidad, se impone desde el individuo, frente a estructuras tradicionales de dominación social, étnica, cultural y política antes hegemónicas. Explicamos e insistimos, que el estudio de los "ambulantes" investigados, están enmarcados en un espacio muy específico, que es el lugar co-vecinal al gran megamercado de Lima Norte ${ }^{31}$, ubicado en los distritos de Los Olivos e Independencia, que denominamos también complejo comercial, a la que acuden gran parte de esta población. Desde luego, no podemos orientarnos bajo las miradas de la vieja Lima desde la literatura o las narrativas de antaño, tratando de mirarse el ombligo negativa o positivamente ${ }^{32}$. Describimos más bien un espacio social, en función a los cambios que han ocurrido en los últimos decenios y que los sujetos en investigación proponen.

Los datos referenciales, nos señalan que muchos de ellos se encuentran ante un Centro Histórico de Lima aún "tradicional" no obstante, de "todos los peruanos", donde pensarse limeño es porque "aquí hice mi negocio", "aqui naci y estoy orgulloso", y "obtuve trabajo", a pesar de responder que es una labor para sobrevivir. Desde estas perspectivas, en realidad, Lima ya es de todos los peruanos según los "ambulantes" y, puede considerarse ya, una Capital más diversa culturalmente descrita, pero a la vez bajo una construcción de una sociedad incrustada culturalmente, en pos de su constitución y, dentro de su heterogeneidad, que hace sólo un par de décadas atrás, se veía como excluyente y discriminatoria para los mismos sujetos en investigación. Quizás es lo que auguraba Carlos Iván Degregori (1983) en gran parte de sus trabajos, cuando observaba la constitución de una cultura peruana cuyo eje se veía en el complejo canto-fiesta-danzamúsica, cuyo sentido de lo peruano se reivindicaba desde la cultura. Aquí lo analizamos, con las mismas características pero donde sale a relucir, la categoría "imaginario" que nos da paso a la cultura desde los espacios de "socialización individual-colectivista originaria", cuyas características

\footnotetext{
30 Ver Bibliografía.

31 En el centro el Megaplaza de Lima Norte.

32 Ver: Arroyo E., 1999.
} 
centrales surgen del razonar la naturaleza y particularidad de la familia extensa peruana. Entender, que la diversión en familia, el paseo en familia, la compra en familia y los gustos (musicales y festivos) colectivizados y redistributivos llevan a reivindicar nuevamente la idea de identidad pero en espacios modernizados tardíos como son los grandes malls de Lima Norte, bajo actitudes y comportamientos de un individualismo capitalista que incluso, dentro de la transgresión de las reglas producto del mismo capitalismo a ultranza, aún referimos u observamos una individualidad cuyas pautas se construyen bajo patrones culturales históricos, cuyo carácter es su distinción social con el mundo postmoderno europeo. La idea es entender la diversidad cultural en su sentido de heterogeneidad, como concepto-eje, donde la justicia, la equidad y el derecho no estén exentos de la misma. Nuestra preocupación, en cómo los individuos -en este caso los "ambulantes de la calle"- relacionan un espacio que trasciende la lógica del territorio y se abre a su parte más estructural explícita, desde sus relaciones de trabajo en los negocios o, en el espacio construido, como es la vivienda $\mathrm{y}$, también la producción unifamiliar pero, aún reproduciendo su representación extensa en la ciudad. Desde luego, no necesariamente nuclear a la primermundista, pero sí re-socializada a su manera peruanaandina. Entonces, no es la reivindicación de lo colectivo tradicional, ni de lo individual-andino, esencializado desde la antropología hace muchos años atrás, sino de cómo dicho individuo bajo los mismos patrones y, las originarias historias se acerca y trasgrede la modernización contemporánea, negada no solo por cuestiones estructurales, sino porque debajo de ella la discriminación racial sepultaba dicha movilización socio-cultural. Es decir, se enfrenta y demanda igualdad y derechos, respeto y tolerancia. En el fondo, los comportamientos percibidos por los ancianos, bajo una supeditación étnica-racial, se elude en estos momentos -y en las encuestas-, a pesar de la dura dominación económica explícita, para pensar en el otro, los nosotros, más inclusivo. Después de todo, la pregunta sigue siendo la misma: ¿porqué en todas las encuestas realizadas, responden en su mayoría no haber sido discriminados, en el fondo "choleados" o "serraneados"? Quizás una hipótesis extendida, a la que decíamos anteriormente es que el espacio social y cultural, lo construyen a su manera y también lo reivindican, lo historizan y, lo hacen suyo muchas veces, hasta por contraposición. Por ello la peculiaridad multicéntrica de esta ciudad capital.

Desde luego, bajo estas miradas, no obstante, tenemos una Lima ya provinciana o ya "chola constituida", bajo un individualismo capitalista, que se debe mirar de distinta manera. En todo caso, a todo ello no hacen falta las 
voces disímiles de encontrar un fuerte choque étnico-racial-cultural, que aún sigue persistiendo en algunos centros exclusivos de la Capital. Sin embargo, reiteramos esta tesis que, de alguna forma revelamos en un primer momento, para el sector micro-empresarial, como parte de un seguimiento exclusivo a estos sectores que merodean los grandes shopping centers de Lima Norte. Pero esta vez, la realizamos con los vendedores en la calle o "ambulantes" de modo específico. Aglomeración, que en un primer momento lo tomamos como un universo en conjunto con los demás comerciantes y vendedores formales de los recintos vecinales, que en el fondo siguen la lógica del conjunto salvo excepciones nimias en las respuestas de las encuestas.

\section{REFERENCIAS BIBLIOGRÁFICAS}

ADAMS, Norma y Néstor Valdivia

1994/1991 Los otros empresarios. Ética de migrantes y formación de empresas en Lima. Lima: IEP.

ALTAMIRANO, Teófilo

1996 Exclusión y Cultura. En: Figueroa, Sulmont y Alarcón. Exclusión y desigualdad social en el Perú. Lima: OIT/IIEL/PNUD. pp.116-151.

ALTHAUS, Jaime de

2007 La revolución capitalista en el Perú. Lima: FCE.

AMAT Y LEON, Carlos.

2006 El Perú nuestro de cada día. Nueve ensayos para discutir y decidir. Lima: UP.

ARELLANO, Rolando

2010 Al medio hay sitio. El crecimiento social según los estilos de vida. Lima: Planeta / Arellano Marketing.

ARELLANO, Rolando y David Burgos

2004 La ciudad de los Reyes, de los Chávez y los Quispe. Lima: Epensa / Arellano Marketing.

ARROYO, Eduardo

1999 Visión narcisista e imágenes sobre Lima. Lima: Scientia, No 1, Año 1, Revsita del CIURP. 
AUGÉ, Marc

1998 Hacia una antropología de los mundos contemporáneos. Barcelona: Gedisa.

BAUDRILLARD, Jean

2000 El objeto de consumo. En: CROCI, Paula y Alejandra VITALE. (Compiladoras). Los cuerpos dóciles. Hacia un tratado de la moda. Argentina: La Marca.

BAUMAN, Zygmunt

2007 Vida de consumo. México: FCE.

BOURDIEU, Pierre

2002 Las estructuras sociales de la economía. Buenos Aires: manantial

CASTELLS, Manuel

2002 La era de la información. El poder de la identidad. Vol. II. Madrid: Alianza.

CLIFFORD, James

1988 The Predicament of Culture. Twentieth Century Etnography, Literatur, and Art. Cambridge, Massachusetts and London, England: Harvard University Press.

DEGREGORI, Carlos Iván

1983 Lima: Conflicto Social, Cultura e Identidad. Conversatorio. Lima: Tarea. No.8. Noviembre. pp.16-57.

2000 Panorama de la antropología en el Perú: del estudio del Otro a la construcción de un Nosotros diverso. En: Degregori, C.I. (2000): No hay país más diverso. Compendio de antropología peruana. Lima: IEP/PUC/UP.

DEGREGORI, Carlos; Cecilia BLONDET y Nicolás LYNCH 1986 Conquistadores de un Nuevo Mundo. De Invasores a Ciudadanos en San Martín de Porres. Lima: IEP.

DELGADO, Manuel

1999 El animal público. Hacia una antropología de los espacios urbanos. Barcelona: Anagrama. 
DE SOTO, Hernando

1987 El Otro Sendero. La Revolución Informal. Lima: ILD.

FRANCO, Carlos

1993 “Exploraciones en 'otra modernidad': de la Migración a la Plebe Urbana". En Urbano, H. (Editor): Modernidad en los Andes. Cusco: CBC. pp. 189-227.

GARCÍA CANCLINI, Néstor

1995 Consumidores y ciudadanos. Conflictos multiculturales de la globalización. México: Grijalbo.

1997 Imaginarios urbanos. Buenos Aires: Eudeba.

GIDDENS, Anthony

1997/1991 Modernidad e identidad del yo. El yo y la sociedad en la época contemporánea. Barcelona: Península.

GOLTE, Jürgen

2003 La diversidad de los andes precoloniales, sus consecuencias para los modos de incorporación a la Colonia y la diversidad regional y étnica en el presente. Lima: Investigaciones Sociales. IIHS-UNMSM. Año VII, No 11.

IWASAKI, Fernando

1988 Nación peruana: entelequia o utopía. Lima: Crese.

HALL, Stuart

2010 Sin garantías. Trayectorias y problemáticas en estudios culturales. Lima: E. Restrepo y otros/ Envion /IESC Pensar/ UASB/ IEP.

JACINTO, Pedro

$2007^{\mathrm{a}}$ Modernidad, identidad y representaciones limeñas. Lima: Scientia $\mathrm{N}^{\circ}$ 9. Vol. IX. CIURP.

$2007^{\text {b }}$ Otros gustos, otras costumbres y otros consumos. Los microempresarios frente a los megamercados. Revista Investigaciones $\mathrm{N}^{\circ} 17$. Lima: IIHS. UNMSM.

2011 Entre la cultura y la civilización: la idea de poder en el panorama mundial actual. En. Fernando Rosas (Editor). Historia de la Civilización. Aproximaciones al proceso histórico del sistema capitalista. (siglo XIII - XXI). Lima: Editorial Universitaria-Universidad Ricardo Palma. 
2012 Micronegocios VS. Megamercados. Otros sentidos de identidad, distinción y consumo en los microempresarios de Lima Norte. Lima, Tesis de Doctorado. UPG-Ciencias Sociales. UNMSM.

JÁUREGUI, Carlos A.

2005 Canibalia. Canibalismo, calibanismo, antropofagia cultural y consumo en América Latina. Ensayos de teoría cultural. Iberoamericana Vervuert. La Habana: Premio Casa de las Américas, 2005.

\section{LASH, Scott}

2005/2002 Crítica de la información. Buenos Aires: Amorrortu.

\section{LIPOVETSKY, Gilles}

2007 La felicidad paradójica. Ensayo sobre la sociedad de hiperconsumo. Barcelona: Anagrama.

LÓPEZ, Santiago y otros (Editores)

2001 Estudios culturales, discursos, poderes y pulsiones. Lima: Red para el Desarrollo de las ciencias sociales en el Perú.

MAALOUF, Amin

1999 Identidades asesinas. Madrid: Alianza.

MATOS MAR, José

2011 Estado desbordado y sociedad nacional emergente. Lima: Centro de Investigación de la Universidad Ricardo Palma.

MEJÍA, Julio

2009 Sociedad, cultura y cambio en América Latina. Lima: URP. Departamento Académico de Humanidades / PEB.

MONTOYA, Rodrigo

2010 El porvenir de la cultura quechua en Perú. Desde Lima, Villa El Salvador y Puquio. Lima: Oxfam/ UNMSM/CONACAMI/ CAOI.

MOULIAN, Tomás

1998 El consumo me consume. Santiago de Chile: LOM. Libro del ciudadano. 
PORTOCARRERO, Gonzalo y Jorge Komadina

2001 Modelos de identidad y sentidos de pertenencia en Perú y Bolivia. Lima: IEP.

PORTOCARRERO, Gonzalo (Editor).

1998 Las clases medias. Entre la pretensión y la incertidumbre. Lima: Sur, Casa de estudios del socialismo / Oxfam.

PORTOCARRERO, Gonzalo

1993 Ajuste de Cuentas: Cuatro años de TEMPO. En: TEMPO. Los Nuevos Limeños. Sueños, fervores y caminos en el mundo popular. Lima: SUR./Tafos.

QUIJANO, Aníbal

1998 La Economía Popular y Sus Caminos en América Latina. Lima: Mosca Azul/ CEIS-CECOSAM.

QUIJANO, Aníbal

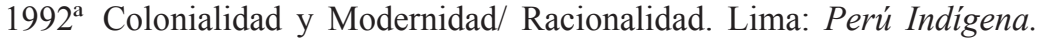
Vol.13. No.29. pp.11-20.

SILVA, Armando

2009 Los imaginarios nos habitan. Lima: UNI / Quito: Olacchi.

UBILLUZ, Juan Carlos

2010 Nuevos súbditos. Cinismo y perversión en la sociedad contemporánea. Lima: Instituto Estudios Peruanos.

VICH, Víctor

2001 Sobre cultura, heterogeneidad y diferencia. LOPEZ, Santiago y otros (Editores). Estudios culturales, discursos, poderes y pulsiones. Lima: Red para el Desarrollo de las ciencias sociales en el Perú. 